


\section{ANNIVERSARY ADDRESS}

DELIVERED BEFORE THE

\section{A MERICAN INSTITUTE}

OF THE CITY OF NEW-YORK,

AT THE

BROADWAY TABERNACLE, OCTOBER 17, 1845,

DURING THE

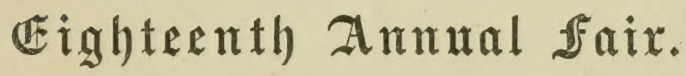

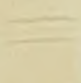

BY THE

HoN. T. D. E L I O T,

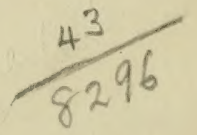

Of New-Bedford, Mass.

DVew inork:

JAMES VAN NORDEN \& CO., PRINTERS,

No. 60 Willtam-streEt.

1845 . 



\section{A D D R E S S.}

\section{Mr. President, and Gentlemen of the Institute:}

There is in the history of the past, this suggestive custom recorded ; - In one of the cities of Peleponnesus at certain times all the inhabitants assembled. They divided themselves into three large companies, of the aged, the mature, and the young. Each had its speaker. When they had gone in procession through the streets of the city, and before yet the games began, a scenic exhibition was prepared, in which each company took part.

And first came forward the old men, whose years were well nigh numbered. They had fought their fight. The toil of life and all its honours, were things of memory. The high endeavour, the reach for fame, the senate, the battle-field! as they looked back, it was the past that told of them.

Sadly, for it was past; but proudly for it had been, their voice was heard-

\section{"We have been in days of old, \\ Wise and generous, brave and bold!"}

Then their sons, the active men, whose manly arms and matured minds sustained the state, came forth, and as they cast their eyes around them, in the consciousness of present strength, they said

\section{"That which in days of yore ye were,} We at the present moment are!"

And having spoken, they gave place, and the children presented themselves upon the stage, their young hearts untouched by disappointment, their faces full of hope and bright with joy; and with clear voice, their vows were offered,

\section{"Hereafter at our country's call, \\ We promise to surpass you all !"}

There was much meaning in this brief play. The past, the present, the future, were thus brought together. The achievements of the fathers, the living power of the sons, the promise of the children. What the state had to remember, what to depend upon, what to expect! It was the voice of year's gone, addressing the present ; inciting to a growth in wisdom, and to surpassing deeds of valour, which coming years should witness, and with which they should be crowned. There was, it is true, one purpose shadowed forth in 
which we may not sympathize; for all that is of war, is uncongenial here. The dust of the field, not of the camp; the sickle, not the sword; bleaching powder, not gun powder; "mechanic powers," not armed forces, betoken our pursuits; for in them are our reliance and our strength. Our national history a single life may well nigh compass. But that brief past has laid us under obligations to the future, which must be recognised. From time to time these obligations should be considered. Nor can more suitable occasions offer than when at the close of these festive gatherings of the friends of domestic labour, we meet to take our annual observation, and make a new departure. Our position as a people is peculiar. But yesterday, our fields were forests. The axe has levelled them, and the sword secured to us their use. The generations which have passed away had their duties, and have performed them. Ours are to be performed, and their performance rests with us, and with us alone. These duties are of a character which the past has in some respect defined for us. And this will always be more or less observable, for in each age the point of progress attained, indicates a further point to be attained, and somewhat opens the path to be pursued. As in journeying over mountains, the traveller looking beyond him upon his winding road a few feet, sees the bold hillside obstruet his path, and knows not whither his true course lies, but shall quickly find as he goes on, that the road just travelled will itself disclose the outlet; so to each generation the great duties of life which are to be discharged, are made plain by the progress of the past. The work of the past has been completed; but our inheritance was costly as it is rich. Those who bequeathed, purchased it at no small sum. The ties of blood sundered, the home and the hearth-stone left, accustomed comforts put away, an untrodden wilderness and unknown foes encountered, life perilled for uncertain good-these made up the first cost. But the outlay did not end here. What was sought for conscience sake and had been gained, could not be lightly parted with. The strong arm must defend what the strong heart achieved. Again, the ties of family were severed, and under auspices which promised success to those alone who knew that "difficulties show what men are," the responsibilities of freedom were assumed. Less than seventy years have elapsed, and what a work has been accomplished. In every department of industry the great results of labour are enjoyed. Agriculture, the oldest and the purest of human callings, has drawn to itself the awakened mind of those who till the soil. Throughout large portions of our land no stream can pour itself idly into the sea: upon its banks the busy man has planted himself, and makes available its waters. The quick noise of machinery is heard, where but few years ago no sound disturbed the silence which nature keeps where man has not approached. The accumulated labour of the farmer and the manufacturer, the merchant receives, and the freighted ship bears the large surplus to foreign lands, whence other products may be returned for their consumption. Where manu- 
factures flourish, and the field is ploughed, and the sails of commerce are spread, the mechanic arts thrive. The inventive skill of a people, is in proportion to the call which is made upon it. When, a few years ago, our countryman whose stern will has compelled the lightning into subjection, sought to exhibit before you the proofs of his strange power, his insulated wires were laid beneath the waters connecting Castle Garden with Governor's Island. It was a moment of keen interest for him and for you. But as he was yet beginning, a vessel by accident destroyed a portion of his conductors, and the experiment failed. "In the moments of mortification," writes Professor Morse, "in a sleepless night I devised a plan for avoiding such accidents in future, by so arranging my wires along the banks of the river, as to cause the water itself to conduct the electricity across." Curiosity induced Franklin to fly his kite. He wished to know whether the flash and the peal from the cloud were caused by the same forces which were confined in the Leyden jar. Accident at an earlier time disclosed the truth, that friction imparted to certain bodies the power of attraction. But neither curiosity nor accident has given to American genius its strongest impulse. When the want has been felt, thought has removed it. And now the fact is ascertained, that when man would make the lightning his messenger, he may compel the river to give it free passage.

By the Jight which falls from the past upon the present, we must read our duty as a Government and as a people. Agriculture, manufactures, commerce, the mechanic arts! What have they done for us? What rather have they not done for us! They are children of one household, and the head of the house should care for them all alike. And thus one duty as a Government is indicated. Excessive legislative interference with individual labour, is hurtful and not helpful to the people. Unequal legislation must be invidious, where equal interests are involved; and although the full grown man needs not the nursing which the child requires, yet the wise parent will guard with jealous care against the charge of partial patronage. At an early period of our history, the fiscal weakness of the Government made it necessary that a line of policy should be marked out, whose immediate consequence was to create a commerce, and to encourage and direct the employment of capital at home. But it has been since the termination of the last war with Great Britain, (let it be the prayer of every good man that it may be permanently our last war,) that by the concurring action of legislation and enterprise, our commercial interests have been enabled to reach their present stature. But neither legislation, nor seamen, nor shipping, nor capital, nor their united power could have attained for us our commercial eminence, if the plough and the loom had been idle. It is our soil that makes the sea of value to us. There are, we know, some seas which our will has converted into soils, and our seamen till them; nor would it become one who lives where the harpoon-plough is used, to forget the seaman farmer, who labours upon the waters by day and by night throughout the year, 
who reaps where he has not sown, and gathers where he has not strawed; whose staple crop is whales, whose works are try works at the best. So intimately connected is the welfare of those great departments of human pursuit, which we at this time represent, that in determining the claims upon us in behalf of one, we set forth substantially the demands of all. And so our first duty springs from that fact of fellowship. Where all are brethren, the love of brethren should exist. Commerce unites these interests and makes them one. Wherever more is made by the hand of man than can be appropriated to the supply of his own immediate wants, that surplus becomes the subject of exchange. The cumforts or the wants of life unsupplied at home are thus provided. From the first barter exchanges of the product of the soil for the simplest articles of skill which social life demands, to those giant enterprises which circle the earth, calling to our use all that the world knows of luxury or science, making the civilization of all preceding time tributary to us, the circuit of the merchant extends over the whole land, and upon every ocean our commerce prevails. No class of men are so high in the social scale as to be above its sphere of action. All ranks of society and all regions of the world are impressed by its energy. The wealth of the nation rests on its successful enterprise. If at once the avenues of commerce should be closed and its ships dismantled, the whole land would be stricken with paralysis. Each of the thousand channels through which labour flows would be narrowed. These considerations justify the regard in which the peaceful pursuits of commerce are held among us. Peaceful they must be, for commerce resting upon contract presupposes peace. But if the prosperity of our country is based on its successful commerce, that success is not self dependent. Commerce leans upon the farmer and the manufacturer, and while she enriches them, draws from them her own support. The merchant exports, buys and sells, but does not make. He uses what others have made, and do not need. If the farmer did not produce or the manufacturer create more than he consumed, there could be no subject for commerce to act upon. The people that are unable to send abroad the products of their soil or of their skill, to procure with them articles of foreign growth or industry, must either be drained of their precious metals, or live destitute of what may not be supplied by their own strength. Accumulation, then, underlies commerce, but that rests upon labour. Here we have reached the foundation principle-labour, human labour! And better foundation need not be laid. It is of divine appointment, and its uses are divine.

\footnotetext{
"Man must labour, nought is sleeping

In the dimmesi, brigh'est zone,

From the worm of painful creeping

To the cherub on his throne!"
}

He that will not labour, or that may not so use his hand or his head as to do somewhat toward the supply of some want, moral, mental or physical, is a half-man at most. His horse is of more service in 
the world than he. But it is not to be forgotten that head labour is as worthy as hand labour. Commerce depends upon the one as much as upon the other. And so does agriculture, and so do the arts. It is the recognition of this truth, and its practical application to the condition of labouring men, that should constitute the present work of those who from the labouring man derive their wealth, and those multiform blessings which wealth throws around them. Here is detected the great duty that has been all too much overlooked, which, by reason of what has been done, the present age demands of us. Of what avail is it that our bags are filled with gold, that our warehouses bend beneath the pressure of their goods; that our ships connect us with the world, pouring our treasures upon foreign soils, and returning richer treasures for our consumption? The aggregate wealth of the nation is enlarged, and individual possessions rival the opulence of rovalty. But what is the condition of the people- of the hundreds of thousands who create-the grower of grain, the operative mechanic, the workman in the factory, the apprentice? This question should be kept in mind until the answer shall not imply a duty unperformed. Before any effective step can be taken in their behalf, that prejudice must be encountered and removed, that the work of the hand is more productive than that of the mind. The thinking man appreciates at once the surpassing productiveness of mental labour. He that stands behind the plough does well; and so did he do well, whose mind contrived the plough with which the soil is turned. Let not the hand say to the head "what doest thou?" nor the head to the hand "what doest thou?" For God has given to every man both hand and head. But these considerations may more properly be pressed in another connection.

I was stating the dependence, one upon the other, of those branches of our industry for whose protection your noble Institute was founded, with a view of showing, that as their interests were joint and their action upon us united, so they demand of us the performance of certain duties which concern them all. We are, as a nation, and must be, if true to ourselves, emphatically an agricultural people. With the exception of some portion of the northern states, where granite crops are raised, and ice is grown for exportation, and of some sections of the Atlantic coast, there can not be found a land where Providence points more emphatically to the sickle and the plough. There were in the United States, during the last year, no less than seven hundred and twenty-nine millions of bushels of grain raised upon our farms ; and of these, nearly seventy-five millions have been raised in this state. This amount has been ascertained, and falls short, undoubtedly, of the whole crop. Beside these, the tabular estimates which have been published state that $17,715,000$ tons of hay have been cut; that of tobacco, $166,705,000$ pounds have been raised; that $872,107,000$ pounds of cotton have been grown; and 111,759,000 pounds of rice; and 201,107,000 pounds of sugar ; and last, and least in quantity-though our fair friends will think first in quality and of greatest value - that 396,790 
pounds of silk have been produced for their consumption. These constituted the crop of the last year. But these do not fill up the measure of our farming industry; for there are cattle upon more than a thousand hills, and the various articles which they lavishly supply, in life and in death, largely increase the aggregate of the annual tribute which the farmer exacts from the soil he cultivates. Nor can this aggregate be diminished, if the privileges of our condition are not abused. Of our institutions we are naturally and justly proud; for they are the work of our own hands. There is this difference between us and most of our trans-Atlantic brethren: that with them, their institutions make the men, but here, our men have made their institutions. It is possible that we are too prone to magnify them. Those who "kneel before the king" charge this offence upon us. It may be a just charge. They partake of our own imperfections. Until man ceases to be human, no form of government or institution of society can be perfected by him. We believe that something has been done, when man may stand upright and worship God as he shall choose-when he may work and "shall receive his own reward according to his own labour ;" when he may speak, and fear no man, so long as he shall wrong no man; when, being wronged, the laws afford him suitable and quick redress; when the man of one dollar, who is true to himself, is more esteemed than the man of a million dollars who is false; when laws are equal; when, not wealth, nor social elevation, nor accident of birth, nor tenure of office-but Truth, holds the scale; where Justice dwells. If these things are so among us, something has been done; - not all, however ; for where free institutions have been planted, man has a right to look for better fruit than "bonds!" The tree of liberty should not be girdled by a chain! But we bide God's time, knowing that out of evil He educeth good. But whether we may or may not be chargeable with extravagant self-love when we speak of our form of government, of our institutions, of our laws, of anything that we ourselves have designed or ordained, we subject ourselves to no such charge in describing the varied beauties of our land, the versatile productiveness of its soil, its rich mountain regions and broad valleys, where, away from the rude clashing of rival interests, our farmers pursue their pure and healthful calling. Where has God bestowed upon his children such a heritage as we enjoy! Of this we may surely boast. But as we survey this broad extent and these boundless resources of our land, where climates rival soils in rich variety; her mountains clasping the heavens, her green fields waving in the sunlight, her borders girded by the ocean, her bosom severed by mighty and rushing rivers and pierced by lakes, themselves ocean-like; and more than all, remember that her sons are free-subject to no restraints, amenable to no laws, accountable to no tribunals not self-imposed and instituted, we are constrained to acknowledge the fearful trust, and to seek the duties it involves: for neither country, nor institutions, nor diverse endowments, shall redeem us from strict account. 
Of the great and growing amount of agricultural produce which the different sections of our land afford, what, and how, and where is the consumption?

First, at home! for nineteen millions of men are to be sustained, and can obtain sustenance from no foreign source. The farmer feeds the country. His unostentatious labour makes the heart of the land to beat with life. But his surplus food would be of litile worth if no market were open to him except that which he himself could find. His sphere is at home. It is there his virtues shine. He thrives not in the din which men make, but in the quiet which God has stamped on his creation. When the harvest has been gathered in, and the granaries bend under their weight, and the work of the farmer has ended, the merchant and the ship stand ready, and with quick haste the varied products are scattered upon the wings of the wind and steam, by river and by lake, along the iron road or upon the ocean wave, throughuut our own borders, and wherever upon the earth there are men to be supplied. Such are the calling of the farmer and the aids the merchant renders him. Is it not passing strange that where interests so intertwined are manifest, aught of jealous feeling should put asunder what has been thus joined together? There is with us a singular closeness and unity between these leading pursuits. For the commerce of most vital import to us as a nation striving for individual and aggregate advancement, for the altainment and security of solid comfort, is not that whose stage is the world, but that whose design and scope is confined at home. You live here in the focus of commercial light and heat. The keen contest for mastery in the difficult carecr of life has secured for you the wreath of the victor. We yield the palm to you with one voice. Your rich city is our queen of commerce. She stands upon her own proud monument. But its base rests on the soil we tread upon. The farmer by his hard toil has worked for you; the manufacturer, who from the raw material has wrought out his fabrics by a magic whose quick and potent spells would but a few years back in the history of the world have invoked the ban of witchcraft ; and the genius of mechanical indus. try, warmed into life and rendered strong and active by the demands which the farmer and the loom have created-these all have worked for you, and at your hands claim encouragement, protection, patronage.

There have existed commercial cities whose bright career has startled the generations that beheld their growth, which have been made great by foreign enterprise. About three thousand years ago Carthage was built. A wandering queen landed with her retinue upon a small isthmus, scarcely three miles broad, near a bold promontory which divides the southern shore of the Mediterranean. Her Canaanitish ancestors had left their homes when Joshua led his hosts through the divided waters. She fled from the cruel oppression of her brother, to found upon the African coast a nation that should rival Rome in great possessions. For her first "real 
estate" Dido is said to have paid even less than the sharpest white man of modern days allowed the Indian for his inheritance. Fo" a small consideration she bargained for as much land as the hide of an ox would compass. Her simple customers, who deserved the cuw-hide rather, readily agreed. But the Tyrian exile, bringing to her aid the mechanic arts, caused the skin to be cut into long strips, and so enclosed a territory whose breadth satisfied her and quite astonished them. In this branch of business no man has yet outDidoed the queen of Carthage. In commerce Carthage had no rival. IIer marine was placed by old historians above that of the world beside. All the ports of the Mediterranean were familiar to her, and were visited for purposes of traffic. From the farthest east then known, to regions in the west, beyond which no Columbus hat explored, her busy mariners traversed. The mercantile skill and success of the Carthagenian extorted praise from the father of history. But it was not to domestic agriculture that she was indebted. Her merchants enjoyed the carrying trade of the world. To her manufactures and her still in the mechanical arts she owed much, and from her Tyrian ancestry derived that genius which compelled the Roman historians to designate as Punic the most remarkable results of inventive skill. But although domestic agriculture contributed so little to her growth, it would be difficult to estimate the value to her of agricultural industry; for she availed herself of the produce of the world, and by consummate skill made other granaries answer to her call. But for the successful prosecution of our commerce, our own resources are sufficient. We need no Sicilian or Sardinian colonies. Within ourselves we possess all that soil or climate may afford for domestic use or foreign export. What they supply, however, would quickly and inevitably compose a stock which commerce could not easily dispose of, if from our own shores the raw material and that alone were to be shipped. And thus the necessity exists for the protection and encouragement here at our own dorrs of the third of those great interests, whose triple alliance shall confirm and establish each other, and can alone perfect our self relying strength. For no nation is independent whose essential wants are unsupplied at home. Nor has the lesson of the past been learned, if we are not yet convinced that the people who only raise but do not make, are in no condition to deal on equal grounds with foreign industry. If the physical strength of our nation should be expended on the soil, not only would the acecessible marliets abroad be overstocked, but the muscle and sinew of our men would be foreed to wage an unequal war with the half paid labour of the world beside.

Such is uot the destiny which God has marked out for us, if we use his gifts aright ; for not reason alone, but nature, would condemn us, if as a people in very truth we take no thought wherewithal we shall be elofhed. The thousand water falls, whose voices chorus the music of the forests, would comdemn us ; for their significant notes have not fallen upon dead ears. IVe hava understood their 
meaning as plainly as if the genius whom the old mythologies placed over them, should rise from their green banks to interpret it in literal speech. These running rivers were made for human use, as truly as the soils they nourish. The poet who dreams beside the brooks may sorrow if the discord of earthly machinery shall interrupt the song of the stream; but the man-if he be poet ton-in that machinery itself, complete in all its parts, and by volition seeming to perform its work, coming in aid of the running waters, and enabling them to minister in a new form to human wants, shall read a perfect poem, the great idea of which God gave to man.

In respect to this great interest which has within a few years past absorbed such vast amounts of capital, and controlled to such extent human labour, it is not singular, perhaps, that the opinions of practical statesmen have varied, and that even now such diverse views are entertained by men who, with equal honesty of purpose, would promote the public good. It was but sixty-four years ago that Thomas Jefferson said, "Such is our attachment to agriculture, and such our preference for forcign manufictures, that, be it wise or unwise, our people will certainly return as soon as they can to the raising raw materials, and exchanging them for finer manutactures than they are able to execute themselves."

But sixty-four years, when the wurld moves by machinery, is a Methuselah's life; and if that eminent philosopher had anticipated the realities which these days disclose, he had also foreseen how admirably, under his own institutions, the finest manufactures of Europe might be rivalled by a people whose attachment to agriculture remained unshaken.

Facts are surer guides than theories can be.

"Experience is by industry achieved, And perfecied by the swift course of time."

What the measure of protection is that Government may most wisely extend, it is no part of my present purpose to consider. But two conclusions the past has established; that a permanent and steady policy should be pursued, and that protection as such should be so applied, that the favour granted may not prejudicially affect interests equally important, and deserving equal consideration.

Of the value of our manufactures as a means of supplying our home wants, no difference of opinion can exist. Our experience has been too recent and too impressive, not to have convinced us that the same parental care with which other nations have uniformly guarded the labour of the subject, must be assumed and felt by nur own toward that of the citizen, if the citizen and the subject are to trade together upon terms of reciprocal advantage. Such considerations concern us at present, only as they tend to make plain the intimate union of those interests which this Institute would encourage. I do not believe in the truth of the position, that if the manufacturer is helped, the merchant or the farmer is by consequence hurt. 
That partial legislation is possible, we know ; but that because the life and health of one was preserved, the others must fall sick, is a theory all fancy-built. For what are our manufactures wanted? That labour may be profitably emplinyed; that all the people shall not, in the words of Mr. Jefferson, return to the raising of raw materials; that our citizen producer shall not be at the mercy of the subject manufacturer; that we may not be for ever compelled to exchange raw material, which is cheap, being mainly the product of labour, for the same material, after foreign mind and skill have quadrupled its worth; that so we may not by compulsion pay a bounty upon foreign intelligent skill. Have we not mind lying fallow, and skill which only craves opportunity? Have not our waters head enough to turn machinery? Must we too go to the river Jordan? Are not Abana and Pharpar as good as the waters of Israel?

We have sincerest respect for the surpassing energy with which England, in one sense foreign, yet in the highest and truest no stranger to us, has pressed onward in her carcer. She has marched with giant stride toward the fulfilling of her destiny. In looking upon her, we may remember that it is "excellent to have a giant strength;" but must not forget "how tyrannous 'twould be to use it like a giant." Our manulactures were born of our necessities. It was because food could not cover the nakedness of the land that the citizen farmer made cloth. Timely encouragement and endeavour, undismayed by reverse, have already won success; and now the manufacturer seeks for his material from the soil which is tilled; from the buried ore exposed to view; from the forests that are levelled; from the seas that are explored; from inanimate and inorganic matter, and from all grades of life below our own.

Facts yearly pressed upon nur notice demonstrate the great and growing demand that, by reason of these nurseries of creative force, exists for all products which directly sustain life, and which, by the agency of steam and the application of skill, are turned to man's account. The surest guaranty of peace that any people can have, until peace shall be loved for its own sake more honestly than among the nations it has been hitherto, is the possession, within itsclf, of those means of defence, and of support, which may enable it to stand self-poised and self-reliant. With an agricultural strength competent to ineet promptly all demands upon it, and manufacturing industry and power equal to any emergency, while we cherish, upon principle, good-will toward men, we may rest assured that occasions of offence will less frequently arise and more quickly be removed.

The energy which has recently advanced so rapidly these industrial pursuits, has given an impulse to the mind of our people, which has filled the land with proots of their inventive genius. From the valuable report of Mr. Ellsworth, we Jearn that there have been in the United States, prior to January, 1815, fourteen thousand and twenty-four patents issued, five hundred and two of which were granted during the present year, In 1841 , one thousand and forty. 
five applications for patents were made at Washington. Of the five hundred and forty-three applicants who were refused, probably the far greater number were ignorant that the principle of their inventions had been earlier ascertained. They were their inventions, none the less, truly ; and if to these it were possible to add the many improvements in machinery, of more or less value, the use of which has not been secured to the inventor by patent, the aggregate of inventive skill among us for the last twelve months would betoken an energy of thought which no nation upon earth has rivalled.

It would be a hard task to enumerate the uses to which the few elementary mechanical powers have been applied since the commencement of the present century. Machinery has supplanted human labour everywhere. All things which necessity demands or luxury solicits, the machine makes. It wards off from man the heat of summer, and protects him from the cold. It supplies him with food and raiment. It ministers to his intellectual wants-laying open before him all the ways of knowledge. If he would lie down, it makes and furnishes his couch. If he would move, it lifts him up-bearing him with the speed of thought where he would be borne. The powers of nature are constrained to serve freely and without price when man by machinery involics them. The waters are made to work. The wind cannot blow where it listeth. The quick lightning has been compelled to come and to go, and to do errands for its unrelenting master. How extensively electricity may be available upon the farm, we cannot yet foresee. The idea of this use of it belongs to a lady, who poured electric fluid from her conservatory into her terrace through a wire, and the grass, to her amazement, grew green in winter, and the snow was melted from the surface, while all surrounding vegetation was stiff and white. Upon this hint, aiter some few years, a thoughteful agriculturist acted, and by a simple process conducting eleciricity from the air to the roots of plants, demonstrated that this invisible power might be successfully applied to the uses of the farm.

And now, as I am speaking, our newspapers, which have this advantage over electricity, that nothing is so isolated that they cannot reach it, are telling us that in your neighbouring city of Philadelphia a musical instrument has been invented upon new principles"the active agent being electro-magnetism, which, passing through wires, breathes forth sounds equaling the Eolian harp in sofiness, and rivalling the organ in the distinctness of its notes." And so it seems to have become a literal truth, that by the agency of human will, acting through simple machines of hurnan contrivance, the lightning, this mightiest of nature's forces, may be so tamed for scrvice that it will work in the garden for the farmer-making his vegctables grow, or play in the parlour for his wife-putting her to sleep with its sweet music!

Without pausing to calculate the market value of these singular appropriations of the energies of nature, what room for reflection is there in the fact that man is able thus to seize and convert to his own 
use the subtilest elements! How by a little thought he multiplies his strength! Standing alone, who so weak, so helpless as he. Yet has he reduced the world to himself. Without external aid he could accomplish nothing. But he does accomplish all things, compelling all to be his agents and to work his will.

The arts are the humanizers of life; all that is not of the earth in man has been elevated as they have advanced. They have been the handmaids of religion, and have done her good service in the world, the ruder and the finer arts alike. All arts are fine arts, and the useful the finest. IVe look upon the statue of an old master, or upon the breathing marble of Powers, and our hearts swell with delight, for we see the truth cmbodied there. So also is the truth embodied in the nicely adjusted machine which decp thought conceived and exquisite skill wrought out. The steam-ship is a work of fine art'as truly as a picture of the waters she moves upon or the shores she visits; and he who fashioned it, adapting each nicely adjusted part so as best to effect the end proposed, has as clear an eye for the beautiful and the true, as the artist who breathes out his soul in the creations of the pencil. And so in this outer world, where nature by her "peaceful strivings and doings," addresses us in that combined "outline of cloud, and sky, and sea, and coast, sleeping in the morning or the evening light."

"The hills

Rock ribbed and ancient as the sun-the vales

Stretching in pensive quietness between

The venerable woods-rivers that move

In majesty, and the complaining brooks

That make the meadows green; and, poured round all,

Old ocean's gray and melancholy waste!"

Here are pictures which Zimmerman may not equal. But more exquisite than these is this machine-the human hand-the suppliant servant of the mind!

But it is the mechanic arts, as encouraged by the demands of the farmer, the manufacturer, and the merchant, that interest us now. The machine is the instrument with which the art is earried on. It is itself a work of art, contrived to increase human power and enlarge its sphere of action. By its aid a single man worlis with an hundred hands, and so becomes fifty men, and ceases to be one. But if mechanic arts are not fostered, inventive skill would be unknown, for its want would not be felt. Thought is the parent of invention-not necessity. Necessity awaliens thought; and so it will be found that in those arts which have not been successfully pursued, for lack of proper instruments, machines, tools, the want has aroused thought, and the needed invention has followed. At the close of an interesting report made by Mr. Charles M. Keller to the late Superintencent of Patents, this lact is stated, that "those branches of the arts which have been in a prosperous condition during the past two years, as for instance cotton manulictures, have received a smaller number of contributions from inventors, than those which have been in a depressed state, as civil enginecring." 
In proportion, then-and here is the point which I would now establish-as the need is felt of improved machinery, inventive skill is developed and mechanic arts advance; and that necessity is recognised in the precise proportion that commerce and those associate pursuits, whose joint progress we are assembled to promote, are encouraged by our government and ourselvẹs.

Thus it is apparent how, in our country, and under our institutions, these great interests, by mutual action, advance each other. And so that duty before alluded to, results of balanced and impartial patronage.

But the past imposes another work upon the present. And all imperfectly as I have discharged thus far the office which your favour, not my deserving, has assigned me, you would esteem it blameworthy if that were not considered. For who are they that constitute the strength of the prominent branches of human industry? Who fill the granaries of the land, and make available the loom, and work out in their thousand lowly ways the varied defences, and comforts, and luxuries of life? The results of labour are all around us. We see them in the temple of God, in the palace of the rich man, in the iron ship, in the magnificent works which adorn your city, and in that especially by which the waters of a river are conjured from their bed to supply your wants.

But where is the labourer, and what is done for him? We claim with earnest voice protection for ourselves, and legislation responds to the call. Our manufactures are extended, and commerce multiplies her sails, and in their growth, agriculture and the arts live and thrive. But the great end of this is national and individual wealth; and that end has been gained, and therein we rejoice. But the success which has marked our progress, and crowned our work, is itself a trust, and its responsibilities we may not fly from if we would.

Men who are endeavouring by legislative enactment and individual effort to meliorate the condition of the labouring classes, complain, and perhaps with truth, that the rates of compensation enjoyed so poorly remunerate them for the stipulated work; and if we go into the field or the workshop to ascertain what is done for those whose lives are expended in producing the first results of labour, we may find much room for sad speculation. There is something wrong here, that requires the application of thought for its removal.

But there are considerations which more appropriately address themselves to us here and now. Gathered together for purposes national in their character, it is not enough that we congratulate ourselves on that proof of success which great possessions furnish. There are other interests than those which the "dollar" represents; and though uncounted, thousands reward our efforts, we have failed, have we not, if we have liept out of sight the clains of those, without whose labour-spent lives we had hecn poor indeed.

The great work which the present has to perform, is to contribute of its strength to lift up the labourer, and to make him more and 
more a man. The cultivated farmer is better than the cultivated firm. An instructed mechanic who appreciates the principles of his trade, applying science to labour, is as removed from the untaught workman whose only knowledge is to use his tools, as the dead machine from the cunning hand that formed it. Nor is there room to doubt that from the classes of labouring men themselves, upon the farm, in the workshop and the factory, a cry is coming up for help to those who alone may aid them. In the promotion of agricultural schools and associations, of apprentices' libraries, of mechanics' institutes, we read the signs. They are not to be mistaken. They mark one era in our history that is full of promise. Never before have such things been seen as now. But of himself, the labouring man can do little. From his youth up, the hours of his life have been toil-worn. He needs encouragement, assistance, sympathy. And he looks for these things from you. Shall he look in vain? But what is to be done? That is an important question; but after all it is not there the great battle is to be fought. When conviction is heartfelt that something should be done, the work is half accomplished. It is when the feeling is skin deep only, and is not conviction, that difficulties start up and questions are put. He who is thoroughly persuaded that he has a work to do, is more than half informed how he is to do it. But to us the question is answered. We know what is to be done. From the highest rank in society to the humblest walk, a cord extends, that unites the two extremes. The one is to be elevated, or both must sink.

Labour demands knowledge, and the cry must be heeded. Not the knowledge of books, nor yet of men, but that knowledge of the principle of things applicable to itself in its various phases and forms, whereby it shall become labour effectire, and not labour lost. We need not invite the labourer into the fields of general learning, nor are we called upon to enter them ourselves. But in those departments which illustrate his pursuits, it is as right, yes, and as needful, too, that the operative upon the farm should be instructed, as that the professional man should be wise in the learning of his school. We recognise our dutics to the young, and in the common schools established and spread throughout the land, we testify our faith in education. Let that faith be unshalien, for our hopes rest on the young. But that is not enough. 'The professional student is urged onward by richly endowed colleges and learned lectures, where experiment refutes error and establishes truth. So let the mechanic and the agricultural student be helped onward in their career. We should not williugly commit our rights or health to the care of one unprepared by diligent study for his work! Is no preparation requisite by him who would solicit from the earth its treasures? 'The physician by careful labour investigates the causes of disease, and by minute analysis defines the action of each remedy. IIe studies the pliysical constitution of his paticnt, and not blindly, but with thought and foresight acts.

The farmer is the physician of the soil-the foctor of grains and 
grasses. He should know when and why to drain off hurtful fluids, to neutralize noxious elements, and correct destructive tendencies. He must learn to knock reverently at the door where nature keeps her mysteries concealed from vulgar gaze. But if he do thus knock, it shall be opened to him. In your own state, not less than five hundred thousand men compose her agricultural strength. Of these how few there are who listen with living ear to nature's teachings. Yet her laws are simple and uniform, and from the diligent inquirer she never turns away. Between the proud tree of the forest, the monarch of a century, and the constitution of the soil which nourishes its roots, there is a close and immediate connection. But centuries passed away, and the oak, and the beech, and the pine, in their several generations, flourished and decayed, before this simple truth was revealed to man. Between the solid trunk and spreading branch, and the grains and grasses that grow upon the same soil, the same intimate and beautiful relationship exists.

The scientific agriculturist, who ascertains what constituents compose his soils, and the various grains which he would grow, has in his own hand the law which God established, and by which he works in his creation; for not a blade of grass nor blushing flower springs up by the wayside, that owes not its life, and its beauty, and its fragrance to laws which $\mathrm{He}$ ordained, but which by earnest seeking man may find out. The ploughman who whistles as he works "for want of thought," will not read the book before him, for he does not know that it is opened. It is a sealed volume to him, while all the time to the open eye its pages glow with beauty and instruction. Under the surface of the earth there is a soil where other elements exist in different combinations, and with his plough he turns it up to the fresh air, mixing the two soils together, so that each shall supply the other the strength it needs. But of the process going on before his eye, he is ignorant, and ignorant without fault. From early childhood he has awaked day by day to the same dull round of toil; suspended only by the welcome night, that his wearied body might be strengthened for renewed labour.

But his children may know, for now the time is at hand when the claims of labour shall be heard.

"Far back in the ages

The plough with wreathes was crowned,

The hand of kings and sages

Entwined the chaplet round,

Till men of spoil disdained the toil

By which the world was nourished,

And dews of blood enriched the soil

Where green their laurels flourished;

Now, the world her fault repairs !

The guilt that stains her story,

And weeps her crimes, amid the cares

That formed her earliest glory."

But her earliest glory did not shine with the lustre that shall crown her brow when science shall weave the wreath and the labourer shall wear it. 
There are in other lands, esteemed free, and favoured above most of the nations of the earth, obstacles which the constitution of society presents to those who acknowledge the rights of labour, and advocate its elaims. Where men are classed by birth, and titled proprietors own the soil, which descended from their fathers, and must be transmitted unalicnated to the generations that shall succeed, the lot of the labourer may be with difficulty improved. But here, thank God, we are not cursed by institutions which stamp the freeman as a slave because he tills the ground. From his humble cottage, the farmer's boy may walk by quick step into the high places of honourable trust, nor is there any home so lowly that may not send forth its son to judge or rule the land. With us the labourer is also the freeholder; and that one fact removes us by a gulf worldwide from the proudest nations of the earth. To own the soil he cultivates is the rare privilege which our labourer enjoys. The home he lives in is his own. From the hearth-stone around which parent and child gather, and from which the prayer and the hymn ascend, no man shall separate him. The trees that he plants, ripen for him their fruits. The flocks that he foeds, yield to him their fleece. The grass grows for his use, and the brook that murmurs by his door no power in the land may turn from its shallow berl.

There is in the condition of our labouring classes no obstacle in the way of those who seek their elevation; but all those privileges which they enjoy, not only prepare them to aid in the great work, but furnish us with stimulating motive for exertion. That which is true of the labourer in the field, applies with equal force to the operative in the factory, and the artisan in the shop. What of wealth we enjoy is traceable directly to their labours, and at our hands they jointly and justly demand consideration, sympathy, instruction.

In this Institute, whose eighteenth anniversary has now been held, and to whose great and growing usefulness the industry of the country bears witness, we see a pledge that the claims of the American labourer will not be overlooked. Not from the Eimpire State, but from the Union, the labourer comes up to this high festival. The ingenious mechanic, who without your aid might live unknown, brings here his oflering, and receives from you the hand of fellowship. The manufacturer contributes his beautiful creations-the works and wonders of machinery and skill. The harvest moon is in the full, and by its soft light the farmer bears his fruits. All who essay by apt invention to multiply the comforts or the luxuries of life, exhibit here their models, and explain their curious mechanism; and to all alike, sympathy, encouragement, reward, are here extended. Nor may we be unmindful of that gentle, loving encouragement which woman grants. Better than all legrislative protection, is that which the true woman gives to the industry of her land. Let her, too, be mindful of them that labour: of their real humanity, of their claims to sympathy, and with her persunsive voice assert their rights. With such aids the work is well begun. Agricultural 
schools, the Mechanics' Institute, the lecture-room, the lyceum, the library, these are our machinery; and from the material of native mind a fabric shall be wrought richer than cloth of gold. For

"What constitutes a state!

Not high raised battlement and laboured mound, Thick wall or moated gate;

Not cities proud, with spires and turrets crowned, Not bays and broad armed ports,

Where, laughing at the storm, rich navies ride;

But men-high-minded men!

With powers as far above dull brutes endued, In forest, brake or den,

As beasts excel cold rocks and brambles rude; Men, who their duties know,

And know their rights !" 




\section{LIBRARY OF CONGRESS}

||||||||||||||||||||||||||||||||||||||||||||||| 